\title{
: BEZBEDNOSNA PROVERA - KONTROVERZE U RADU ORGANA BEZBEDNOSTI (komparativni pravni i bezbednosni pristup)
}

\author{
Zoran Dragišić, Dragan Manojlović i Vojislav Jović
} Univerzitet u Beogradu, Fakultet bezbednosti

\begin{abstract}
$\Delta$ utori su u radu sproveli komparativno istraživanje o procesu personalne bezbednosne provere nad građaninom koji se prijavio na konkurs za rad u državnim organima u svetu i Srbiji. Istraživanje je usmereno na definisanje bezbednosne provere i utvrđivanje bezbednosne smetnje u pravnoj i bezbednosnoj teoriji u svetu i u Srbiji - po prvi put. Kroz studije slučaja u pravnoj i bezbednosnoj literaturi u svetu, komparativnom, analizom postojeće literature, pravnom, istorijskom i metodom ankete, istraženo je nekoliko primera kojima se ukazuje na odnose demokratskog i nedemoktaskog društva i država prema primeni prava u bezbednosnoj proveri. Rezultati istraživanja upućuju da bi u Srbiji trebalo da dođe do promena u pravnim aktima i bezbednosnoj metodici procesa vršenja bezbednosne provere, kao i odnosa bezbednosnih organa prema pravima građana koji apliciraju na konkurse gde je bezbednosna provera sastavni deo procesa. Iz navedenog verujemo da rad može da nas uvede u ovaj teorijski izuzetno interesantan i istovremeno za praksu veoma značajan problem.
\end{abstract}

Ključne reči: bezbednosna provera, bezbednosna dozvola, građanin, pravo na rad, konkurs za prijam na posao

JEL: K, K4, K42

\section{Uvodna razmatranja}

/eć nekoliko decenija problem bezbednosne provere je nesumnjivo jedan od onih koji se nalaze u središtu pažnje teoretičara i stručne javnosti u svetu i Srbiji. To nije slučajno: za ovakvo interesovanje za problem bezbednosne provere postoje najmanje dva razloga. Pre svega, reč je o jednom od onih bezbednosnih, pravnih i etičkih problema čiji se neposredni i veliki praktični značaj uopšte ne mora posebno isticati. Bezbednosno i pravno razmatrati problem bezbednosne provere zapravo znači nastojati da se naučno iskaže, dorekne i, možda, razreši jedna dilema sa kojom se bezbroj građana, menadžera bezbednosti i pravnika, svakodnevno na veoma ozbiljan način suočavaju. Drugi razlog je teorijski: problem bezbednosne provere je izuzetno pogodan - možda bi se čak moglo reći najpogodniji - za suočavanje i kritičko naučno ispitivanje odnosa međunarodnih i nacionalnih pravnih pravila, demokratskih i totalitarnih društava i država. 
Kao osnovu za teorijsko i empirijsko prepoznavanje, odnosno identifikaciju predmeta i problema istraživanja, u radu smo izneli samo neke bitne elemente (osnovna obeležja) bezbednosne provere i definisali njen pojam. Nakon ovog uvoda, komparativnom i metodom studije slučaja, primenom metoda analize postojeće literature istraživali smo pravni, etički i bezbednosni pristup pri vršenju bezbednosne provere, čime smo ukazali na postojeće nedostatke u teoriji i praksi rada organa na prostoru Republike Srbije.

U istraživanju u skladu sa obimom i namerom ovog rada, postavili smo nekoliko pitanja, kao što su: Da li je negativna bezbednosna provera bez obrazloženja u Srbiji i nemanje prava na prigovor pravna tekovina pravno i bezbednosno prosvećenih naroda? ${ }^{1}$ Koje značenje ima negativna bezbednosna provera za bezbednosni i pravni status građanina „neprijatelj“ ili nešto drugo? Da li postoji kolektivna odgovornost porodice iz pravnog aspekta? Da li je građanin dostojan u Republici Srbiji, da zna zašto je „persona non grata“, za državnu administraciju nakon što podnese zahtev za prijem u radni odnos, koju plaća i koja na osnovu njegovih prava crpi svoja ovlašćenja, a ne obrnuto, ili svojih diskrecionih prava? Jedno od krucijalnih pitanja koje je u neposrednoj korelaciji sa bezbednosnom proverom je status građanina u nedemokratskim - autoritarnim i demokratskim društvima, moralno - politička podobnost ili vrednost? Da li je kao što veliki broj pravnih teoretičara u svetu zastupa: moralno - politička podobnost osveta? Stanovište većine autora je, da su demokratska pravna dostignuća prosvećenih i civilizovanih naroda i država, ${ }^{2}$ suprotna od totalitarnih stanovišta i prakse bezbednosne provere, koja se sprovodi na osnovu nižih pravnih akata koji po pravilu nisu dostupni javnosti. Iz aspekta ovog rada, razume se da je predmet istraživanja ograničen samo na bezbednosnu proveru koja se odnosi na zasnivanje radnog odnosa u državnim organima. U radu nismo istraživali druge aspekte bezbednosne provere, kao što su: provera osetljivosti mete; ugroženosti izvora; ugroženosti operacije koja je u toku ili se priprema i druge. Nadalje, ovde nismo istraživali bezbednosne provere koje se odvijaju u kontinuitetu, ${ }^{3}$ već bezbednosnu proveru koja se odvija „ad hoc“ nakon podnošenja zahteva za prijem u radni odnos u državni organ, koja se još u bezbednosnoj teoriji naziva i integralna. Takođe, zbog obima ovog istraživanja, nismo istraživali sva tri aspekta bezbednosne provere: ${ }^{4}$ a) interni; b) eksterni i v) problemski, kao ni njene nivoe: a) centralizovani i b) decentralizovani, te podele u zavisnosti od toga ko je sprovodi: a) civilna ili b) vojna (odbrambena ili istražna, policijska, kriminalistička i dr.) agencija. Nadalje, u radu nisu obrađeni ni organizacioni oblici ni modeli, kao ni lokacija agencija koje sprovode procese bezbednosne provere, kao što su: a) integralni model ili b) eksterni model. Prevashodno smo istraživa-

\footnotetext{
${ }^{1}$... u mislima drevnih mislilaca Mojsija, Hamurabija, Platona, Antigone i dr... nalazimo njihova zalaganja za proklamovanjem ljudskih vrednosti kao neprikosnovenih naspram ustanovljenih autoritarnih poredaka...

2 Thomas Buergenthal: International Numah Rights, St. Paul, Minn, USA, West Publishing, 1988.

${ }^{3}$ Constitution and statutes of the United States, including section 1753 of the Revised Statutes of the United States (5 U.S.C. 631); the Civil Service Act of 1883 (22 Stat. 403; 5 U.S.C. 632, et seq.); section 9A of the act of August 2, 1939, 53 Stat. 1148 (5 U.S.C. 118j); and the act of August 26, 1950, 64 Stat. 476 (5 U.S.C. 22-1, et seq.)... koji obuhvata više sekcija, a u jednoj od sekcija (broj 4) se ukazuje na nužnost respektovanja prava građanina koji je subjekt personalne bezbednosne provere...

${ }^{4}$ Pristupi i stanovišta mnogih agencija u čijoj je nadležnosti bezbednosna provera ukazuju da... nivoi i elementi bezbednosne provere variraju od države do države, ali je cilj ovog procesa skoro ili uvek ista... sa jedne strane, ali se metodika i etička odgovornost agencija, kao i primena pravnih propisa sa druge strane, veoma razlikuje u demokratskim i nedemokratskim državama ...Defense Investigative Service...
} 
li aspekt eksterne personalne bezbednosne provere, jer je uporedni parametar u ovom kontekstu eksterni javni konkurs na koji građanin aplicira. Bezbednosni teoretičari ukazuju da je više nego potrebno učiniti jasnu razliku u pogledu interne i eksterne personalne bezbednosne provere, ne samo iz aspekta primene pravnih propisa, već i iz aspekta cilja i zahteva koji se postavlja.

U teoriji i stručnoj javnosti mogu se pronaći raznoliki pristupi kada se određuje pravo i bezbednost u državi. ${ }^{5}$ Tako, prema stanovištu velikog broja autora, mogli bismo reći da Zakon i bezbednost spadaju u odgovornost države. Bez obzira što je ovo stanovište u teoriji preovlađujuće, smatramo da ono nije najpreciznije, jer bezbednost spada u odgovornost ne samo države. No, iz aspekta našeg istraživanja, za nas je upravo ovo stanovište značajno. ${ }^{6}$ Smatra se da je većina država poverila u tim područjima odgovornost nekom organu za primenu prava (Zakona), svejedno da li je to građanski ili vojni organ. $U$ ovom radu pored navedenog, razmotrili smo ulogu tog organa, položaj i primenu prava u bezbednosnoj proveri.

\section{Bezbednosna provera - pojam}

Krenimo od osnovnog etimološkog značenja. Šta je bezbednosna provera? A zatim bismo primenom metoda analize sadržaja svetske teorije i prakse i metodom korelacije istražili njen značaj u bezbednosnom, pravnom i etičkom aspektu. Na osnovu denominatora iz zajedničkih elemenata stanovišta jednog broja autora u pravnoj i bezbednosnoj teoriji, bezbednosnu proveru bismo mogli odrediti kao, proces i proizvod. U tom smislu bezbednosnu proveru bismo razumeli kao proces specifičnog profilisanja namenjen određenoj upotrebi. Na drugom kraju metodološkog pristupa bezbednosnoj proveri u pravnoj i bezbednosnoj teoriji, se mogu pronaći stanovišta koja ukazuju da je personalna (fizičko lice je subjekt) bezbednosna provera proizvod koji nastaje iz tačke međusobnog presecanja saznanja i njihove analize.

Iz aspekta ovog rada smatramo da su dve grupe narednih stanovišta sveobuhvatnija. Prvu grupu stanovišta prihvata veliki broj pravnih i bezbednosnih autora, je ona, koje ukazuje da je bezbednosna provera, određeni koncept koji obuhvata primenu odgovarajućih propisa, metoda, tehnika i alata od strane jednog ili više organa (službi, agencija i dr.) koji omogućava etičko i legalno prikupljanje, obradu i analizu saznanja o predmetu ili subjektu bezbednosne provere. Drugu grupu stanovišta čine oni koji prihvataju navedeni pristup i dodaju, nije dovoljno da se kaže: da bezbednosna provera bude sprovedena određenim metodama i tehnikama, ${ }^{7}$ već je krucijalno da to bude učinjeno nakon adekvatnog izbora i primene određenog metoda i tehnike u zavisnosti od subjekta koji je predmet bezbednosne provere. Ovde se naročito ukazuje na etičnost i legalnost, jer su to po mnogim autorima njena sui generis obeležja, koja je odvajaju od neetičkih i nelegalnih metoda, tehnika i alata. ${ }^{8}$

\footnotetext{
${ }^{5}$ Claudia Aradau: Security and the democratic scene: Desecuritization and emancipation. Journal of International Relations and Development, 2004 7(4): 388-413.

${ }^{6}$ Dinah Shelton, et.al.: Protecting human rights in the Americans: Selected problems, 3rd ed, Kehl, N.P. Engel, 1990.

${ }^{7}$ Hannah Arendt: The Human Condition. Chicago, IL: Chicago University Press, 1985.

8 ... od profesionalnih službenika u državnim organima se traži da se prema vršenju poslova odnose u skladu sa profesijom i nadležnošću službe u kojoj su zaposleni. Da čuvaju njen ugled, da ne govore ništa o procesu
} 
Iz navedenog, bezbednosnu proveru razumemo kao proces koji u sebi sublimiše određenu kombinatoriku odgovarajućih pravnih propisa, etičkih kodeksa, bezbednosnih potencijala (bezbednosnih, kontraobaveštajnih, kriminalističkih, policijskih, obaveštajnih i neobaveštajnih službi, agencija i dr.) i metodike rada organa ${ }^{9}$ koji sprovodi bezbednosnu proveru. U teoriji možemo pronaći da bezbednosna provera ima svoja tri aspekta: a) pravni; b) bezbednosni; i v) etički. Nadalje, mnogi pravni i bezbednosni teoretičari i istraživači ukazuju, da je bezbednosna provera uvek presek ili skup - zajednički imenitelj otvorenih i skrivenih saznanja, na osnovu kojih, kao ishodište nastaje znanje i iz njega odluka, bilo da je pozitivna ili negativa. Dakle, oni smatraju da se bezbednosna provera mora posmatrati kroz odnos i interakciju otvorenih i skrivenih saznanja.

Posmatrano komparativno, u kontekstu navedenih stanovišta u svetskoj pravnoj i bezbednosnoj teoriji, možemo zaključiti da je određenje bezbednosne provere veoma raznoliko. Imajući u vidu navedene primedbe, uvažavajući prethodno navedena stanovišta pri definisanju pojma pokušali smo da damo takvu definiciju bezbednosne provere - koja se u teoriji označava terminom „personalna bezbednosna provera“ ili „,bezbednosna provera subjekta - fizičkog lica" koja će moći da izrazi svu njenu kompleksnost, ali i ujedno da konkretizuje njeno polje istraživanja: Bezbednosna provera po prijemu zahteva za prijem u radni odnos, je koncept i proces koji obuhvata primenu propisa i etičkih principa, adekvatno izabranog metoda, tehnike, alata i izvora, u celini ili integralno, od strane jednog ili više organa, službi ili agencija usmerenih na prikupljanje obaveštenja (saznanja, podataka, informacija, materijalnih činjenica, pravno relevantnih činjenica) iz verifikovanih i formalizovanih izvora, njihovu obradu i analizu, kako bi se ostvarilo pravno, etičko $i$ bezbednosno merenje, procena izvora-otvorenih (dostupnih; poznatih) $i$ skrivenih saznanja o subjektu bezbednosne provere u cilju omogućavanja, osporavanja ili ostvarivanja prava subjekta bezbednosne provere.

Ovde razumemo da bezbednosnu proveru ne smemo poistovetiti sa informacijom, jer su informacije samo deo procesa, iako veoma važne. ${ }^{10}$ Nadalje, krajnji cilj bezbednosne provere jesu informacije, ali to su informacije koje su obrađene, analizirane i profilisane, specifično primenljive na personalnu bezbednosnu proveru aplikanta za zasnivanje radnog odnosa. Takođe, ne bi trebali da upadnemo u zamku da je bezbednosna provera samo prikupljanje informacija, suština je i u proceni prikupljenih informacija, a to znači da govorimo o dva uzajamna procesa: bezbednosna provera i bezbednosna procena u okviru kojih se utvrđuje da li postoje ili ne postoje bezbednosne smetnje. Prikupljanje informacija je samo jedan segment procesa u konceptu bezbednosne provere. Verujemo da su najbliža i ona stanovišta autora koja ukazuju da je personalna bezbednosna provera, jedan segment ili

koji je u toku, o aspektima i rezultatima delatnosti, da čuvaju tajnu... u profesiji je značajna dimenzija etičkih principa... Sve ovo je regulisano Kodeksima koji su zbir profesionalnih i moralnih zapovesti...

${ }^{9}$ lan Johnstone: Dilemmas of robust peace operations' in Annual Reviw of Global Peace Operations, Boulder, Lynne Reiner, 2006.

${ }^{10}$ Čuveni Ruski pisac Lav Nikolajevič Tolstoj (rus. Lev Nikoláevič Tolstóŭ) (1828-1910) u svojoj knjizi „Put u život" daje osnove vrednosne polazišne osnove kada se vrši provera nekog lica. On kaže... „Čoveka nikada neće hvaliti svi. Ako je dobar, on će za „nevaljalca“ biti rđav, pa će mu se nevaljalci smejati i osuđivati ga. Ako je zao, dobri se neće saglašavati sa njim. Kada bi čovek hteo da ga svi hvale, on bi pred dobrima trebalo da se predstavlja dobrim, a kod rđavih rđavim..... Ovo je polazna osnova za notiranje i merenje validnosti izvora... 
posebna poslovna funkcija u organima, službama i agencijama. Bitno je razumeti da bezbednosna provera nije i ne može biti svedena samo na neku od faza, koje smo naveli, već je to celovit ciklus koji se odvija ad hoc, u kojem svaka pojedina faza ima svoje strogo određeno mesto i ulogu u procesu koji se završava proizvodom. ${ }^{11}$ Taj proizvod u bezbednosnoj teoriji pojedinih autori označavaju kao bezbednosna znanje ili proizvod. ${ }^{12}$

Za istraživanje u ovom radu, naročito je značajno da smo dali i jedan sublimat stanovišta one pravne teorijske misli u svetu, koja se ne upušta u pozitivno određenje bezbednosne provere, davanjem njene definicije, već ukazuje šta bezbednosna provera ne sme i šta treba da bude. Tako, se navodi sledeće: bezbednosna provera ne sme biti sredstvo/instrument u kapacitetu i ovlašćenju državnih organa, dato im bez propisanih zakonskih normi, kojim se ometaju ili uskraćuju građanska i ljudska prava, već pravni mehanizam sa jasno definisanim procesom, ${ }^{13}$ normama ovlašćenja i ograničenja, na osnovu nacionalnih i međunarodnih pravnih instrumenata, ${ }^{14}$ da se izgradi profil aplikanta na konkursu, u skladu sa njegovim građanskim i ljudskim pravima i jasno definisanim i određenim bezbednosnim instrumentima, etičkim principima, radi omogućavanja ili uskraćivanja njegovih prava. Ova stanovišta naročito ukazuju, da nije u skladu sa pravnim principima demokratskih društava: prekrivanje nalaza $i$ odluke organa u procesu personalne bezbednosne provere tzv. "diskrecionim pravom", koje u pozitivnim pravnim propisima totalitarnih sistema/režima, u koje se svrstavaju i zemlje koje se nalaze u prelasku iz totalitarnog u demokratski sistem vlasti, nije definisano od strane zakonodavne vlasti, već se određuje voljom samog organa. Nadalje se navodi, da se nekontrolisanim (nedefinisanim internim aktima) diskrecionim pravom organ ${ }^{15}$ građanin - aplikant na konkursu za rad u državnom organu, ne potčinjava zakonima, već drugim licima i organima, što je suprotno svim međunarodnim pravnim aktima iz oblasti ljudskih i građanskih prava. ${ }^{16}$

\footnotetext{
${ }^{11}$ www.odci.gov/cia/publications

${ }^{12}$ Pravni i bezbednosni teoretičari stoje na stanovištu da bezbednosna provera nema potreban pravni legalitet i legitimitet ukoliko izvori iz kojih su prikupljana saznajna, bez obzira kog su nivoa, nisu provereni-nisu podvrgnuti proceni-validnosti. Nadalje, autori ukazuju da ovakva bezbednosna provera nema pravni (zakonit) kapacitet da se na njoj utemelji bezbednosna provera, odnosno konačna odluka (pozitivna ili negativna). Jedan broj pravnih teoretičara ukazuje da je u pravnoj teoriji u svetu nesporno: da bezbednosna provera bez procene validnosti izvora i saznanja iz tih izvora, koja je vidljiva u tekstu samog pismena (bezbednosne provere) verifikovana u „fus noti“, gde je za svaki iskaz ili tvrdnju izvršena procena validnosti sa jasnim prikazom, koja metodologija i metodi su primenjeni, nema pravni ni etički legitimitet- Ona nije van svake sumnje. Prema međunarodnim pravnim aktima i pravom poretku prosvećenih naroda ukazuju autori, građanin može tražiti da se saznanja koja nisu tačna ili su obmanjujuća moraju proveriti naknadno. U nekim pravnim situacijama građanin ima mogućnost da pokrene postupak pred sudom za iskaze koje je izvor izneo, pa je stoga procena izvora i njegova notifikacija obavezna u samoj bezbednosnoj proveri. Notifikacija izvora u bezbednosnoj proveri je uslov upotrebe izvora...

${ }^{13}$ Amitov Acharya, The Quest for Identity, International Relations of Soutbeast Asia, Oxford, Oxford University Press, 2000.

${ }^{14}$ Michel Akehurst: Modern Introduction to International Law, 6th ed, New Delhi, UBS, 1992.

${ }^{15}$... iz istraživanja se uočava prisustvo navedenih instrumenata diskrecionog prava u Srbiji-prekrivanje nalaza i odluke po bezbednosnoj proveri, diskrecionim pravom i jednim nivoom tajnosti... uz ćutanje organa...

${ }^{16}$...građanin može biti potčinjen samo zakonima, ali ne i drugim licima ili organima. Ovo je osnovni postulat civilizovanih i prosvećenih naroda...
} 
Da li i koliko vredi znanje koje je proizvod bezbednosne provere ${ }^{17}$ Ujedno ovo je jedno od ključnih pitanja koje se postavlja od strane autora u pravnoj i bezbednosnoj teoriji i stručnoj praksi. Na žalost, na to pitanje nije uvek lako odgovoriti: može biti prilično teško predstaviti vrednost bezbednosne provere. Sa jedne strane, to je skopčano sa mogućnošću da se znanje kao vrednost bezbednosne provere pokaže kao nedovoljno ili pogrešno, a sa druge strane da ono bude zakasnelo, kako primećuju autori: da bude suviše kasno kada su u pitanju najviši - najosetljiviji nivoi, kada funkcija „osiguranja“ (jedna od funkcija bezbednosne provere) izostane.

\section{Zašto je bezbednosna provera tako vredna?}

Profesija i rad je jedna od čovekovih suština. Svaki čovek želi da radi nešto i trudi se da za tu delatnost ima znanja i veštine, koje mu omogućavaju da dužnost obavlja kvalitetno i sa uspehom. Pojam profesija označava upravo to -posedovanje znanja (struke, poziva, radne dužnosti) i posedovanje saznanja, veština i uslova za takve delatnosti. Dok uči, pripremajući se za određenu delatnost, on razmišlja da će mu to obezbediti pravo na rad, sredstva za opstanak, a to ujedno predstavlja način na koji se on ostvaruje i jeste njegov lični pečat. Iz navedenog razumemo da je pitanje prava na rad i profesija jedno od najznačajnijih u čovekom životu, a problem pronalaska posla je jedan od krucijalnih u njegovoj životnoj orijentaciji.

Svaka ličnost/građanin stanovište je teorije, razmišlja dugo o profesionalnoj orijentaciji, angažuje se da završi školu, obuku (i to što je moguće bolje) trudi se da nađe i započne posao. To svaku ličnost opseda u mislima, a to joj je lično i veliki životni zadatak. Školovanjem i obrazovanjem građanin, želi da uspe, ima nadu i nastojanje da postigne životni uspeh pomoću svoje profesije. Sve ovo ukazuju teoretičari izražava visoke životne težnje i ideale ličnosti i zbog toga je to izraz unutrašnjih zamisli, ciljeva i dostignuća.

Kada govorimo o pravu na rad i ostvarenje svoje profesije u državnom organu iz aspekta bezbednosne provere, treba razmisliti da li je sve napred navedeno dovoljno? Dakle, sa jedne strane mislimo na racionalnost koja predstavlja manifestovanje svesti građanina o sebi. Sa druge strane mislimo, da li je ovde potreban više nego u nekim drugim pristupima pravu na rad i ostvarenje svoje profesije, da građanin ima „razum“, o potrebi da njegove ljudske težnje mogu biti zaustavljene - neostvarive diskrecionim pravom - da ne zna zašto ne može da radi baš u tom organu?

Iz navedenog, kada govorimo o bezbednosnoj proveri, nužno se nameće pitanje: da li građanin koji je Ustavom i drugim pravnim propisima kako nacionalnim tako i međunarodnim koje je Srbija ratifikovala, slobodan da planira život, da sledeći pravna i etička pravila ima pravo na rad, kao ličnost koja neposredno psihički i biološki živi? Nadalje, da li je iz aspekta personalne bezbednosne provere samo građanin subjekt izgradnje svog položaja u životu, svog blagostanja, ili je to i diskreciono pravo državnog organa? ${ }^{18} \mathrm{Te}$ da

\footnotetext{
${ }^{17}$...značaj rezultata bezbednosne provere je veliki smatraju teoretičari iz oblasti prava i bezbednosti, kao i stručna praksa... a sama bezbednosna provera je nezaobilazan proces u programu prijema građana za rad u državnim organima sa delatnostima koje se tretiraju kao osetljive iz aspekta bezbednosti...Defense Security Service... US Army and Department of Defense...

${ }^{18}$,... Kako si činio, tako će ti se učiniti; delo tvoje vratiće se na glavu tvoju...' Ov. 15.
} 
li je diskreciono pravo bez prava građanina na obaveštenje, jedan od oblika diskriminacije i potvrda da svako od građana nema prava na sva prava? Razmatrajući postavljena pitanja u daljem radu istražujemo navedene korelacije. ${ }^{19}$ Građanin sa pravom $^{20}$ od svog izbora da postupa po propisanim pravnim i etičkim normama, očekuje korist za kvalitet svog života i da ga niko ne ometa u tome. Iz navedenog proističe sledeće pitanje: u čemu se sastoji etički problem bezbednosne provere? Etički problem autori vide u tome: mogu li se navesti takvi razlozi koji će moći da opravdaju nanošenje zla bezbednosnom proverom i uskraćivanjem pozitivnog mišljenja - dakle ne izricanjem presude od strane suda? I ako je to moguće, koji su to razlozi?

Mnogi građani misle na osnovu napred iznetog, sa pravom, a to im garantuju međunarodni pravni akti koje je Srbija ratifikovala, ne samo da mogu da idu u državne agencije, službe i organe i prijave se na konkurs za zaposlenje, već da budu ravnopravni sa svim drugim kandidatima - da započnu posao i ostvarenje svoje profesije. Sa jedne strane u demokratskim društvima i državama, građanin može da očekuje da će biti obavešten na 'primeren način' dostojan njegovih prava da nije primljen uz predlog i razloge. Veliki broj autora iz oblasti pravnih i bezbednosnih nauka u nedemokratskim društvima i državama, stoje na stanovištu da je ostvarenje prava građanina da bude obavešten uz razloge i predlog, daleko od stvarnosti.

\section{Međunarodni pravni akti i bezbednosna provera}

Ovde se nismo upuštali u razmatranje svih međunarodnih pravnih akata ${ }^{21}$ kao i u određenje njihovog pojma, već pre svega na one međunarodne akte koji imaju neposredno dodirivanje sa bezbednosnom proverom i čije je ostvarivanje uslovljeno bezbednosnom proverom i bezbednosnom dozvolom kao ishodištem bezbednosne provere u vezi sa radnim odnosom. Verujemo da je iz aspekta ovog istraživanja pravi put, da ovaj rad po mnogo čemu istorijski i pionirski u našoj teoriji i praksi, kada istražujemo korelaciju bezbednosne provere i radnog odnosa, započnemo sa onim o čemu su pisali veliki mislioci „Platon i Aristotel“. Oni navode „... naj bolji je onaj poredak u kome ne vladaju ljudi ... nego zakoni..... Nadalje, Aristotel izlažući svoje stanovište i misli o vladavini zakona, kaže „... Zakon je um bez žudnje....". Bez obzira što se razvitak u pravnoj teoriji i praksi ljudskih prava događa posle 1945. godine donošenjem: „Univerzalne deklaracije o ljudskim pravima, Međunarodnog

\footnotetext{
${ }^{19}$...U Sjedinjenim Američkim državama u bilo kom trenutku kada se posmatra proces bezbednosne provere davanja bezbednosne dozvole u procesu...nalazi se oko - 1,5 miliona lica za privatne agencija i do 3 miliona lica za poslove u državnoj administraciji ili kompanijama gde državni organ daje bezbednosnu dozvolu... kao i 500.000 službenika svake godine za razne nivoe unapređenja u poslu, profesiji... u državnim agencijama... Dobijanje bezbednosnog sertifikata po nivoima je ključ...

${ }^{20}$...od ključne je važnosti ovde razumeti, da pravo na diskreciono odlučivanje kada zadobija forme arbitražnog ponašanja, u velikoj meri nanosi štetu pravnoj sigurnosti građana. Ovde se ne sme mešati pravo na diskretnost u radu, što je potrebno naročito kada je bezbednosna provera predmet rada službi ili agencija... a subjekt provere je građanin... to izričito zahtevaju međunarodni akti..

21 ... pravo na život, pravo na slobodu i bezbednost, pravo na zaštitu privatnog života, pravo na slobodu misli, savesti i veroispovesti, pravo na mirno uživanje imovine, politička prava, prava vezana za državljanstvo, sklop prava posebne zaštite porodice i deteta, sloboda kretanja, ekonomska i socijalna prava: pravo na rad, pravo na pravedne i povoljne uslove rada, pravo na obrazovanje i ... mnoga druga.
} 
pakta o građanskim i političkim pravima, Međunarodnog pakta o ekonomskim, socijalnim i kulturnim pravima, Evropske konvencije za zaštitu ljudskih prava i osnovnih sloboda", i mnogih drugih akata", temelji su kada istražujemo korelaciju sa bezbednosnom proverom kao osnovom za zasnivanje radnog odnosa, postavljeni mnogo pre.

Podsetimo, da se osnovna prava čoveka prvi put pojavljuju u povelji Magna Karta Libertatum, koja je sačinjena 15. juna 1215. godine i kao Velika povelja slobode sadrži katalog osnovnih prava čoveka i mehanizam kontrole njihovog poštovanja i sankcionisanja njihovog kršenja. ${ }^{22}$ Nakon prve velike i moderne kodifikacije prava čoveka, ${ }^{23}$ koja se pojavljuje u dokumentima u Americi, kao što su: „Virginia of Rights“ i „Declaration of Indenpedence“, sa kraja osme decenije XVIII veka (1776)", ${ }^{24}$ gde se pored: "... prirodnih prava... kodifikuju i pravo na poslovanje i pravo na težnju ka sreći i sigurnosti“, u drugoj polovini XVIII veka (1789) došlo je do druge velike katalogizacije ljudskih prava, nakon što je doneta francuska „Deklaracija o pravima čoveka i građanina“. U njenom središtu pored drugih prava čoveka i građanina koja nisu od značaja za naše istraživanje, uvode se za naše istraživanje dva krucijalna prava čoveka i građanina „... pravo za jednakošću pred zakonom i još važnije, jednake šanse pristupa javnim službama....". 25

Nadalje, u članu 25. Međunarodnog pakta o građanskim i političkim pravima kaže se: ... svaki građanin, bez ikakvog razlikovanja... i bez nerazumnih ograničenja, ima pravo i mogućnost: da mu bude dostupna, pod opštim uslovima jednakosti, svaka javna služba u njegovoj zemlji. Kao što se može videti, odredbe Međunarodnog pakta o građanskim i političkim pravima, jasno štite pravo pojedinca da učestvuje u javnim poslovima. Autori iz oblasti međunarodnog prava ukazuju da, ovo pravo daje obavezu državi ne samo da se uzdrži od nekih postupaka, već i da preduzima specifične korake koji garantuju građanima slobodno i jednako uživanje ovog prava. ${ }^{26}$ Razume se, ponašanje organa kome je država poverila u područjima prava i bezbednosti odgovornost, suprotno od navedenog može se pripisati državi - njenoj odgovornosti.

U Konvencije Ujedinjenih nacija o pravima deteta, ${ }^{27}$ definisano je, da je dete, svako ljudsko biće koje nije navršilo osamnaest godina života, ako se po zakonu koji se primenjuje na dete, punoletstvo ne stiče ranije. Iz aspekta bezbednosnih provera, njima može biti obuhvaćeno i dete ukoliko je ono kandidat za prijem - upis u školu ili na studije u

\footnotetext{
${ }^{22}$... ona predstavlja rezultat nagodbe engleskog kralja Johna Lacklanda i pobunjenih barona koji su nakon kršenja feudalnih prava svih kategorija i ne slavnih poraza u ratovima, kralju ponovo dali zakletvu na vernost $\mathrm{i}$ pokornost, a za uzvrat kralj je njima dao verbalnu zakletvu da će poštovati njihova tradicionalna prava. Beogradski centar za ljudska prava, Razvoj ideje ljudskih prava, Beograd, 2003, str. 1-59.

${ }^{23}$... za potrebe ovog rada koristićemo se onim stanovištima u teoriji i stručnoj javnosti koje kaže, da pravo predstavlja ono što jedno lice može izneti u kontaktima sa drugim licem i zahtevati da se to poštuje pod uslovom da koristeći to pravo to lice ne sprečava nekog drugog u korišćenju njegovih prava...

${ }^{24}$....ovi dokumenti počivaju na tome da je sam čovek nosilac urođenih ljudskih prava kao prava na život i zaštitu lične slobode, prava na poslovanje i sigurnost svojine... i druga prava.

${ }^{25}$...u njenom središtu su pravo na slobodno ispoljavanje mišljenja, pravo na respektovanje tajnosti prepiske, pravo na slobodu štampe, pravo na slobodu religije, pravo na pobunu protiv samovolje vlasti... itd.

${ }^{26}$ Luis F. Molina: Comments in the universality of the code of conduct for law enforcement officials - Third world legal studies 59, 1990.

${ }^{27}$ Usvojena i otvorena za potpisivanje i ratifikovanje ili pristupanje rezolucijom Generalne skupštine Ujedinjenih nacija 44/25 od 20. novembra 1989. Stupila na snagu 2. Septembra 1990. godine, („Službeni list SFRJ Međunarodni ugovori“, br. 15/1990).
} 
oblasti policijskog obrazovanja. Ovo praktično podrazumeva da je određena vrsta diskriminacije i povrede ljudskih prava na osnovu bezbednosne provere moguća i prema deci, bez obzira što je Konvencija eksplicitna u poštovanju i obezbeđivanju prava bez ikakve diskriminacije zasnovane na statusu, aktivnostima, izraženom mišljenju ili uverenju detetovih roditelja, zakonskih staratelja ili članova porodice (čl. 2), odnosno omogućavanja da više obrazovanje bude dostupno svima u skladu sa sposobnostima (čl. 28).

Univerzalnom deklaracijom o ljudskim pravima, ${ }^{28}$ propisano je da se sva ljudska bića rađaju slobodna i jednaka u dostojanstvu i pravima (čl. 1). Iz aspekta bezbednosnih provera koje vidimo iz istraživanja, postoji mogućnost kršenja prava da svako na ravnopravnoj osnovi stupa u javnu službu u svojoj zemlji (čl. 21), odnosno pravo na rad, na slobodan izbor zaposlenja i zaštitu od nezaposlenosti (čl. 23). ${ }^{29}$

Međunarodnim paktom o ekonomskim, socijalnim i kulturnim pravima, ${ }^{30}$ propisano je da se države ugovornice obavezuju da obezbede jednako pravo muškaraca i žena na korišćenje svih ekonomskih, socijalnih i kulturnih prava (čl. 3). Nadalje je u ovom Paktu propisano da države ugovornice priznaju pravo na rad, koje podrazumeva pravo svakog lica da dobije mogućnost da obezbedi sredstva za život slobodno izabranim i prihvaćenim radom i da će mu država odgovarajućim merama štititi ovo pravo (čl. 6).

\section{Demokratska i nedemokratska društva i države i bezbednosna provera}

\section{Demokratska društva i bezbednosna provera}

U svetskoj teoriji i praksi kada se istražuje oblast primene pravnih, etičkih i bezbednosnih principa i propisa pri vršenju bezbednosne provere kada građanin aplicira na raspisani eksterni (javni) konkurs za prijem u radni odnos u službama, agencijama i organima, ili bez konkursa bude predložen kao kandidat za rad u tim organima i službama, u demokratskim društvima i državama, mogu se pronaći mnogi izvori građe za istraživanje. Bezbednosna provera se danas primenjuje u mnogim zemljama u svetu. Ovo nije slučaj samo u razvijenim demokratskim društvima i državama, kakve su zemlje Evropske unije, Sjedinjenih Američkih Država ${ }^{31}$ i Japana, već i u zemljama sa nedostatkom demokratskih pravnih, etič-

\footnotetext{
${ }^{28}$ Usvojena i proglašena rezolucijom Generalne skupštine Ujedinjenih nacija 217 A (III) od 10. Decembra 1948. godine - Asbjorn Eide., et. al., eds. The Univerzal Deslaration of Human Rights: A Comentary, Oslo: Scandinavian University Press; Ohford University Press, 1992.

${ }^{29}$ Jack Donnelly: Human Rights in Theory and in Practice, Ithaca, New York, Cornell University Press, 1989.

${ }^{30}$ Usvojen i otvoren za potpisivanje i ratifikovanje ili pristupanje rezolucijom Generalne skupštine Ujedinjenih nacija 2200A (XXI) od 16. decembra 1966. godine. Stupio na snagu 3. januara 1976, (Službeni list SFRJMeđunarodni ugovori“, br. 7/1971).

${ }^{31}$... u ovoj demokratskoj državi... na osnovu pozitivnih pravnih propisa... - građanin ukoliko mu je odbijen zahtev za prijem u radni odnos ili dobijanje bezbednosne dozvole nakon bezbednosne provere, odnosno obavljanje poslova i zadatak na osetljivim pozicijama ili pozicijama od posebnog nivoa poverenja... ima pravo prigovora. Pod takvim okolnostima dobiće pismeno i razlog (e) zašto je neprihvatljivo i zašto nema osnova za pokretanje procedura za podnošenje žalbe pred sudskim organima... Ako veruje da saznanja prikupljena o njemu iz izvora (driving records, vehicle registration, credit records, criminal records, social security no., education records, court records,
} 
kih i bezbednosnih pravila. ${ }^{32}$ Mnogi autori ukazuju da se bezbednosna provera sprovodi u svim zemljama, ali su pravni akti, bezbednosni metodi, tehnike i etički principi ostvarenja i zaštite prava građanina koji aplicira na konkurs u mnogome različiti. ${ }^{33}$

U društvima i državama sa razvijenom demokratijom postoje brojni naučni i specijalizovani časopisi u kojima se objavljuju naučni i stručni radovi iz ove oblasti, kao i brojne akademije na kojima se ova oblast izučava. Iz istraživanja postojeće teorijske građe u demokratskim državama, mogu se uočiti razlike koje se mogu grupisati prema pravnim propisima i bezbednosnim metodama i etičkim principima kada se istražuje personalna bezbednosna provera, ${ }^{34}$ shodno: a) njenom intenzitetu (intensity); b) njenom trajanju ( $d u$ ration); v) njenoj sigurnosti (certainity) ili nesigurnost (uncertainity); g) njenoj čistoći (purity - procena izvora, saznanja); d) njenoj blizini (propinquity) ili udaljenosti (remoteness); đ) njenoj plodnosti (fecundity); e) njenoj perfidnosti; ž) formi postupanja (način, oblik delovanja, način ostvarivanja).

Kako je rad usmeren na istraživanje koje se odnosi na aplikaciju na konkurs za prijem u službe, agencije ili organe kao što su: policijska, kriminalističke agencije, tužilaštva, sudovi, bezbednosne agencije gde je bezbednosna provera sastavni deo procesa prijema, ${ }^{35}$ te da je obim našeg istraživanja ograničen ne samo predmetom i problemom već i obimom rada, nesumnjivo je, da je studija slučaja James Vincenzo Capone, dobila primat pored mnoštva drugih u istraživačkoj naučnoj građi demokratskih država, da primenom istorijske metode, i metode studije slučaja, istražimo i prikažemo pravni i bezbednosni pristup demokratskog društva i države prema personalnoj bezbednosnoj proveri i davanju ili uskraćivanju prava na zaposlenje-rad.

workers' compensation, bankruptcy, character references, neighbor interviews, medical records, property ownership, military records, state licensing records, drug test records, past employers, personal references, incarceration records... i mnogi drugi izvori koje ovde nećemo nabrajati) koji su kontaktirani tokom bezbednosne provere su obmanjujuća ili netačna... ima pravo prigovora... biće dat predlog da se to ispravi ili razjasni situacija... u pojedinim situacijama kada je predmet rada interna personalna bezbednosna provera... građaninu će biti omogućeno da razjasni obmanjujuća i netačna saznanja...Security Clearance Appeal Decisions...

32 ... Kada se u bezbednosnoj teoriji potraže podaci kojima želimo da saznamo koliki vremenski period/rok je dozvoljen za proces organu koji vrši bezbednosnu proveru, uočavamo da je za nivo (confidential) poverljivo i (secret) tajna vremenski period od 1 do 3 meseca. Kada se posmatra vremenski rok u kome organ mora da izvrši bezbednosnu proveru i dostavi bezbednosni izveštaj za nivo (top secret) je od 4 do 8 meseci...As a result of the Smith Amendment, the FY01 Defense Authorization Act amended Chapter 49 of Title 10, United States Code...Kada se razmatra pitanje koliko godina obuhvata period u koji ulazi u proces bezbednosne provere (koliko "duboko-vremenski u određene evidencije"...), daćemo samo neke...civil suits, civil judgments, and records of arrest, from date of entry, after seven years, Paid tax liens after seven years, accounts placed for collection after seven years, any other negative information (except criminal convictions) after seven years..

${ }^{33}$... bez obzira što je jednoznačno teško preciznije definisati pravo na demokratsku vladavinu i dati jedno opšte zadovoljavajuće određenje demokratije, istraživanja za potrebe ovog rada mogu dovesti do onoga što je značajnije od navedenih određenja, a to je određivanje demokratskog upravljanja bez obzira na odgovarajući sistem koji vlada u datoj državi. Takve karakteristike uključuju demokratski izabranu vladu, koja je reprezentativna za narod te države i kome je odgovorna (član 21 Međunarodnog pakta o građanskim i političkim pravima); postojanje i poštovanje ljudskih prava i sloboda; poštovanje i potčinjavanje vladavini prava (član 26 istog pakta)... i dr.

${ }^{34}$...primena etičkih principa pri sprovođenju metoda, tehnika i alata u procesu personalne bezbednosne provere je pitanje legalnosti samog procesa i njegovog proizvoda...Personnel Security Questionnaire...

${ }^{35}$ Profesija je jedna od čovekovih suština. Svaki čovek želi da radi „nešto” i trudi se da za tu delatnost ima znanja i veštine, koje mu omogućavaju da dužnost obavlja kvalitetno i sa uspehom. Pojam profesija označava upravo toimanje znanja (struke, poziva, radne dužnosti) i posedovanje znanja, veština i uslova za takve delatnosti... 


\section{Studija slučaja - James Vincenzo Capone}

U ovoj studiji slučaja analizom postojeće literature i deskripcijom prakse, kao i komparativnom i istorijskom metodom, daćemo primer pristupa građaninu i njegovom bezbednosnom aspektu u Sjedinjenim Američkim Državama. Razume se, izlažemo istraživanju jedan od najkapitalnijih primera i pogleda demokratske države i njenih organa na bezbednosne aspekte koje gradi i sa sobom nosi član porodice Kapone - građanin koji konkuriše (aplicira - podnosi zahtev) da radi u državnom organu sa jedne strane, kao i uvažavanje njegovih ljudskih prava - jednog od osnovnih prava: prava na rad sa druge strane, te njegovog prava da ne bude opterećen bezbednosnim aspektima svog člana porodice, u ovom slučaju brata Alfonsa Kaponea i drugih članova njegove porodice braće, sestara, oca i majke, sa treće strane.

Pođimo od početka, porodičnog stanja i aspekta bezbednosnog rizika koju porodica $\mathrm{Ca}$ pone sa sobom nosi, kao i njeni članovi, kako i počinje bezbednosna provera. Da bismo dublje istražili fenomen - bezbednosna provera, postavićemo nekoliko pitanja. Ko je porodica Capone? Da li je svaki drugi član porodice Capone, koji ne učestvuje u kriminalnim aktivnostima, bezbednosno rizičan za državne organe? Da li član porodice Capone koji nema učešća u kriminalnim aktivnostima uživa sva prava u pogledu prava na rad, a time i prava na rad u državnim organima? Da li u demokratskim državama bezbednosna provera derogira pretpostavku nevinosti i prava čoveka i građanina? Da li James Capone ima pravo da bude „Čovečan i profesionalan“ i tada kada njegov najbliži član porodice čini nešto drugo, da čini dobro i ispravno? Da li James Capone bez obzira na svog brata Alfonsa može poštujući pravila dužnosti dosledno i pošteno da radi i živi? Da li je u ovom kapitalnom primeru za demokratiju, demokratska država - Sjedinjenje Američke Države, pokazala da je njena najveća i vrhunska vrednost, da građanin James Capone, oseti da je dostojna ličnost, koja može da postupa moralno i u skladu sa dužnošću i koja je stvarno tako postupala, bez obzira na svog brata Alfonsa Caponea, koga je ta ista država proglasila neprijateljem broj jedan? ${ }^{36}$

Porodica Capone je emigrirala u Sjedinjene Američke Države 1893. godine kada je mali Vincenco (James) imao nepunih godinu dana, u naselje Nejvi Jadr (Nevy Yard) u ulicu Nejvi (Nevy) broj 95, u centru Bruklina u blizini berbernice gde se otac Gabrijel nakon emigracije i useljenja porodice, zaposlio kao berberin u ulici Park Avenija (Park Avenu) broj 29. Iz bračne zajednice Gabrijela i Terezine rođeno je devetoro dece, braća: Vicenco (James), Alfonso (Al), Rafael (Ralf), Salvatore (Frenk), Džon, Albert, Metju, i sestre Rouz i Mafalda.

James Vincenzo Capone je bio najstariji brat Alfonsa Caponea, rođen je u mestu Kastelamare di Stabila u blizini Napulja, država Italija, kao prvo dete u porodici Capone, od oca Gabrijela i majke Terezine, 1. oktobra 1892. godine. Otac Gabrijel Capone, je rođen 12. decembra 1864. godine u mestu Castelammare di Stabila, udaljen 26 kilometara južno od Napulja, po zanimanju je bio berberin. Majka Terezina Capone, rođena je 28. decembra 1867. godine, devojačko Riola, u malom gradu Angrija (Angri), u provinciji Salerno (Salerno), po zanimanju domaćica.

\footnotetext{
${ }^{36}$ Veliki Nemački i svetski filosof i etičar Imanuel Kant (1724-1804), u delu Kritika praktičnog uma... 0 dužnosti..."Dužnosti! - ti uzvišeno, veliko ime, ti što u sebi ne sadržiš i ne podrazumevaš ništa svojevoljno, ništa što sa sobom nosi udvaranje, već traži potčinjavanje, ... pred kojim ćute sve sklonosti, ... koji je tvoj dostojan izvor i gde se nalazi koren tvog plemenitog porekla, koje ponosno odbija svako srodstvo sa naklonošću...?
} 
Sredinom 1908. godine napustio je svoju kuću u Bruklinu kada je imao šesnaest godina. Od malena je imao jaku volju i trudio se da bude nezavisan. Oslanjajući se na svoje vrline, individualnost, ali i svoju odgovornost, poželeo je da koristi tekovine svog razvoja. Odlazi zapadnije gde je shvatio da je prosperitet bolji. Može se reći da je James kao mlad bio snažan i veoma avanturističkog duha. Pridružuje se cirkusu, a to mu je omogućilo da proputuje širom srednjeg zapada. Tada je po prvi put došao u dodir sa indijanskom kulturom, koja ga je fascinirala. Bio je doličan strelac i vičan u rukovanju pištoljem. Prijavljuje se dobrovoljno i učestvuje u Prvom svetskom ratu. Za vreme rata je bio raspoređen u Francuskoj sa više američkih ekspedicionih snaga. Pokazao se veoma dobrim vojnikom. U vojsci za vreme rata je dobio čin poručnika.

Posle završetka Velikog rata, nakon povratka za Ameriku, od kada je otišao iz Bruklina, trudio se da promeni Bruklinski akcenat. Odlazi u Nebrasku, gde 1919. godine u predgrađu Homer (Homer) spašava mladu ženu (Kathleen) i njenu porodicu iz lokalne poplave. Obrazuje se. Iste godine Katlin mu postaje i supruga. Iz bračne zajednice dobijaju četiri sina. Zapošljava se i ubrzo postaje federalni agent za borbu protiv "švercovanja - ilegalnog prometa" alkohola. Zbog velikog broja uspešnih racija, novinari ukazuju na njegovo srodstvo sa porodicom Capone. Sa svojom suprugom i četiri sina seli se iz Homera - Nebraska, jer postaje specijalni američki agent biroa za indijanske poslove. Uspešan je u akcijama sprečavanja, odnosno zadržavanja alkohola izvan indijanskih rezervata. U Južnoj Dakoti mu se poveravaju poslovi lične bezbednosti predsednika Kalvina Kulidze i njegove porodice. Potom po služenoj dužnosti biva premešten u Vašington (indijanski rezervat - „Spokane"), gde njegov predan rad na istragama, prikupljanju i obezbeđenju dokaza omogućuje hapšenje dvadeset lica sa poternice koja su izvršila krivična dela ubistvo. Kao savesnom i darovitom službeniku poverava ${ }^{37}$ mu se mesto oficira za sprovođenje zakona u Plummeru - Idaho, gde ostaje neko vreme, a sredinom 1931. godine po službenoj dužnosti se vraća u Homer - Nebraska kao federalni agent.

Nakon što je 1933. godine ukinut Zakon o zabrani proizvodnje i distribucije alkohola, prestaje sa policijskim radom. Besprekornim ispunjavanjem dužnosti, ostvarenjem na duhovnom i organizacionom planu, savesnost i odgovornost u vršenju poverenih mu dužnosti bivaju preporuke za biranje i uvođenje u red sudija, u Sjedinjenim Američkim Državama.

Iz nalaza uočavamo, da James Capone pokazuje, da za takvu "visoku", jednu od najviših pozicija u jednom demokratskom društvu, ima pravo da se izbori svojom životnom i moralnom orijentacijom i postojanim moralnim delovanjem, sa jedne strane. Sa druge strane pokazuje da kriminalna delatnost njegove braće Capone (Ralfa, Frenka, Alfonsa i dr.) u personalnoj bezbednosnoj proveri, ne sme da bude smetnja za njegovo pravo da svojom životnom i moralnom orijentacijom postojanim i profesionalnim delovanjem bude uvaženi službenik i građanin Sjedinjenih Američkih Država. Sa treće strane pokazuje kapitalnu vrednost za demokratsko društvo - da građanin može biti odgovoran samo za svoja dela i da je samo on subjekt bezbednosne provere, a ne njegov brat, mama, tata ili deda i baba - da ne postoji kolektivna odgovornost porodice. Ova kapitalna suprotnost od koncepta autoritarnih sistema personalne bezbednosne provere, je ključna vododelni-

\footnotetext{
${ }^{37}$ Najpoznatiji rimski filosof i besednik, ali i izuzetno važan državnik, Marko Tulije Ciceron/Kikeron (106-34. pre n. e.), koji je stvorio reč moral, napisao je delo "O dužnostima", čije su ideje bile najuticajnije etičke misli u istoriji. Svojim građanima je ukazao ... da će im život biti uspešan samo ako se oslanjaju na svoje vrline i dela, a ne ako se nadaju nesposobnosti drugih...
} 
ca za svrstavanje jedne države i društva u demokratsko ili autokratsko sa moralnom političkom podobnošću i kršenjem ljudskih prava onoga ko podnosi zahtev za rad u državnom organu, gde je bezbednosna provera nužna kao i bezbednosna dozvola. I onda kada Džeims (James Capone), kontaktira i sastaje se sa članovima svoje porodice, viđa ih, vodi svoje sinove da vide familiju, i Alfonsa (Alfonsa Caponea) koji je tada bio u poodmakloj fazi bolesti, u njega se ne sumnja i ne trpi posledice toga u profesionalnom napredovanju. Ovaj časni Kapone, čiji sin Ričard gubi život u Drugom svetskom ratu, živi u gradiću Homer do 1952. godine kada umire od posledica srčanog udara u 60-oj godini života. Privrženost porodice Džemsu (Jamesu), supruge Ketlin i sinova opredeljuje ih da svoj život nastave da žive u Homeru - Nebraska, gde je Džems (James) i započeo svoju časnu delatnost policajca u agencijama Sjedinjenih Američkih Država.

\section{Moralno - politička podobnost i kolektivna odgovornost porodice}

Ovo istraživanje smo najpre podeliti po periodima: period nakon Drugog svetskog rata do kraja dvadesetog veka u Srbiji i period prve decenije trećeg milenijuma. Nasuprot izloženoj studiji slučaja u društvu i državi koje počiva i baštini demokratske vrednosti u ovoj studiji slučaja izložili smo model koji se primenjuje u nedemokratskim totalitarnim društvima i državama. Istorijskom metodom, metodom ankete i dubinskog intervjua, istražili smo pristup - procesu sprovođenja bezbednosne provere i dobijanje ili uskraćivanja bezbednosne dozvole prema građaninu i njegovom bezbednosnom aspektu u totalitarnom - nedemokratskom društvu i državi. Razume se, istražili smo primere nedemokratske države i njenih organa na bezbednosne aspekte koje gradi i sa sobom nosi porodica i član porodice građanina koji konkuriše (aplicira - podnosi prijavu) da radi u državnom organu sa jedne strane, kao i uskraćivanje njegovih ljudskih prava - prava da ne bude opterećen bezbednosnim aspektima svog člana porodice, sa druge strane. Nadalje, istražili smo koliko su u nedemokratskim društvima sa moralno-političkom podobnosti ugroženo osnovno ljudsko pravo građanina - pravo jednakog pristupa svim pravima.

$\mathrm{Na}$ osnovu rezultata empirijskog istraživanja: građanin je rođen u Srbiji, gde je završio osnovnu i srednju školu, a zatim i fakultet. Nakon odsluženja vojnog roka, na predlog prijatelja koji je bio u radnom odnosu u službi bezbednosti, podnosi dokumenata za prijem na rad u službi bezbednosti (službu razumemo kao organ države kome je država poverila određene odgovornosti u bezbednosti). Tada ne osuđivan, nije pod istragom, kao ni članovi njegove porodice. Posle deset meseci, nakon što je podneo dokumenta za prijem na rad i ćutanja od strane službe, dolazi do saznanja da je bezbednosna provera negativna, ${ }^{38}$ odnosno da postoji bezbednosna smetnja za prijem. Tada saznaje da za njega i članove porodice: oca, majku, braću i sestru, nema bezbednosnih smetnji, već da postoje smetnje moralno-političke podobnosti člana porodice - dede, za koga se preko iz-

\footnotetext{
${ }^{38}$ Koliko dugo su validne bezbednosne dozvole koje su nastale kao proizvod bezbednosne provere? U nekim zemljama ne postoji trajna bezbednosna dozvola, već se ponovne provere (reinvestigation) vrše periodično i to: za ovlašćena mesta sa nivoom - top secret na svakih pet godina, za nivo secret na svakih deset godina, a za nivo confidential na petnaest godina...
} 
vora došlo do saznanja da se priklanjao vrednostima koje su bile pre Drugog svetskog rata u Srbiji - nije baštinio politička uverenja tada vladajuće partije.

Istraživanje nas upućuje na više nalaza, kao što su: u totalitarnom društvu od kraja Drugog svetskog rata do kraja dvadesetog veka u Srbiji, postojala je moralno - politička podobnost ${ }^{39}$ i kolektivna odgovornost porodice za građanina koji je želeo da se zaposli u državnoj administraciji - policiji, službama bezbednosti. Deca su snosila odgovornost što su daleki preci mislili drugačije od vladajuće partijske misli - unuk je „persona non grata“ za državne organe kada želi da ostvari svoje ljudsko pravo, jer njegov predak - deda nije bio moralno - politički podoban.

Krajem prve decenije trećeg milenijuma (nazvan demokratskim periodom društva i države) u Srbiji, građanin se prijavljuje za prijem u radni odnos - policiju na javnom konkursu koji je oglašen u dnevnoj štampi. Građanin je državljanin Srbije, nije osuđivan, nije pod istragom, imao je odgovarajući broj godina, nije se pozvao na prigovor savesti, završio je četvorogodišnju školu. Ispunjavao je i druge uslove koji su konkursom definisani kao uslov za apliciranje na konkurs.

Nekoliko dana nakon što je od strane državnog organa sproveden postupak bezbednosne provere nad članovima njegove porodice, sa kandidatom je obavljan razgovor u njegovom stanu od strane službenog lica koje je sprovodilo postupak personalne bezbednosne provere. U razgovoru sa službenim licem obaveštava se, da nema bezbednosnih smetnji u proveri koja je nad njim sprovedena, ali da službeno lice: veruje da neće biti pozvan na zdravstvene i druge preglede, testiranje i vođenje daljeg postupka u kome bi mogao da iskaže svoje sposobnosti, veštine i znanja kojima bi sebi omogućio ravnopravan status sa svim drugim kandidatima koji su se prijavili na konkursu, da ostvari pravo na rad u državnom organu. Službeno lice veruje da postoje bezbednosne smetnje ${ }^{40}$ člana porodice, koje su smetnja za njegov dalji put kojim bi mogao ostvariti svoja građanska prava.

Građanin nikada nije obavešten od strane organa koji je raspisao javni konkurs na koji je se prijavio da postoje bezbednosne smetnje koje ga diskvalifikuju ${ }^{4}$ - ograničavaju njegova ljudska prava u ostvarenju prava na rad u državnom organu - policiji. ${ }^{42}$ Razume se,

\footnotetext{
${ }^{39}$ Mnogi autori smatraju da na ovaj način bezbednosna provera i bezbednosna dozvola funkcionišu kao sredstvo ideološkog vaspitanja - kako samog kandidata na konkursu, njegove porodice tako i čitavog društva... Nadaje u teoriji možemo pronaći stanovišta koja ukazuju: da se na navedeni način grubo degradira čovek kao vrednost. Jer ako u bezbednosnoj proveri vidimo moralno-političku podobnost - mi vidimo sredstvo za političko-ideološko odgajanje građanina, time što ga oblikuju prema svojoj koncepciji društveno poželjnog.

${ }^{40}$... člana porodice nekoliko godina pre-više od deset, počinio prekršaj za koji mu je od strane sudije za prekršaje izrečena novčana kazna...

${ }^{41}$... u istraživanju koje je sprovedeno, rezultati ukazuju da je $2 \%$ članova porodice kandidata na konkursu počinilo prekršaj pre nego što je sklopljen brak; da je 0,8 \% članova porodice počinilo prekršaj pre nego što je aplikant rođen... 0,7\% otac aplikanta počinio je prekršaj u vreme maloletstva... i dr. Iz istraživanja koje su autori sproveli u periodu 2011/2017.

42 ... jedan broj teoretičara smatra da je jedan od temeljnih problema u nedemokratskim društvima, što policija predstavlja sistem za kažnjavanje pre presude suda. Otvaraju se dosijea građanima na osnovu kvalifikacije događaja onako kako ga policija vidi. Ne retko se događa (neka istraživanja ukazuju u preko 58\%) da građaninu otvore krivični dosije da je izvršilac krivičnog dela, a tužilac nikada ne pokrene postupak (stavi predlog sa sprovođenje istražnih radnji) pa se postavlja pitanje, smatraju autori: policija izriče kvalifikaciju izvršilac, a to je posao i nadležnost suda. Korišćenje takvih kvalifikacija pri bezbednosnoj proveri je krajnje problematično... Ovakav model je na snazi u Republici Srbiji... stat.gov.rs
} 
bezbednosne smetnje kao i u prethodnoj studiji slučaja ne postoje na strani građanina koji je aplicirao na konkurs, već se njegova bezbednosna podobnost ocenjuje na osnovu bezbednosne podobnosti/nepodobnosti člana porodice koji se nije prijavio na konkurs. ${ }^{43}$

Iz istraživanja koje smo izveli uočavamo da u Srbiji, i u trećem milenijumu postoji kontinuitet bezbednosne provere i njenih vrednosti iz perioda posle Drugog svetskog rata. Personalna bezbednosna provera, danas kao i u periodu posle Drugog svetskog rata, nije usmerena na podnosioca zahteva za prijem na rad u državni organ, već na druge građane - njegove članove porodice. ${ }^{44}$ Ovakav pravni i bezbednosni pristup da podnosilac $^{45}$ koji se prijavljuje na konkurs bude „persona non grata“ zbog člana porodice, suprotan je pravilima prosvećenih naroda i država i međunarodnim dokumentima koje je Srbija ratifikovala, što je predmet istraživanja u drugim delovima ovog rada. Da li se ovakvim pristupom grade i baštine vrednosti demokratskih društava i država, verujemo da ćemo razumeti iz istraživanja koje je u ovom radu izvedeno?

Komparativnim istraživanjem za potrebe ovog rada prikazali smo, da bismo shvatili odnos demokratskog i nedemokratskog društva - odnose i stanovišta u teorijskim i stručnim studijama, istraživanjima i naučnoj misli o kolektivnoj odgovornosti porodice pri bezbednosnoj proveri. Pravna misao demokratskih društava nasuprot stanovištima u studijama slučaja građanina u Srbiji, zastupa stanovište, da je kolektivna odgovornost porodice kandidata (građanina) na konkursu za rad u državnom organu svojstvena totalitarnim režimima iz aspekta pravne nauke i teorije, nedopustiva. Sa druge strane, upozorava se da je kolektivna odgovornost najčešće sprovođena za vreme rata (razume se zabranjena je međunarodnim aktima); da je to bilo svojstveno krvnoj osveti, ili modelu delovanja i shvatanju odgovornosti unutar mafije.

Teorijska misao demokratskih društava, razmatrajući odgovornost građanina za delikte člana porodice koje on nije počinio, ima umnogome suprotno stanovište od stanovišta nedemokratskih sistema i država time i pravnog i bezbednosnog pristupa u Srbiji. ${ }^{47}$ Ukoliko je osnovni princip personalne bezbednosne provere, provera člana porodice i to stavljanje na teret licu koje se prijavilo na konkurs- njegovo dovođenje u povoljniji položaj za omogućavanje ili uskraćivanje prava na rad, autori u pravnoj teoriji u svetu, postavljaju pitanje, šta činiti kada je: a) otac podnosioca dokumenata na konkurs nepoznat (što je legitimno pravo) - da li to znači da nije krivično odgovarao, ili da nije u vremenu kada se sprovodi proces po konkurs na izdržavanju kazne?; b) kada je podnosilac dokumenata

${ }^{43}$... u demokratskom društvu Sjedinjenim Američkim Država-građanin (T.M.) aplicira na konkurs za rad u policiji. lako je imao evidentiran delikt koji je počinio (prevedeno na zakon krivični u Srbiji iz oštećenja imovine-u SAD-pisanje grafita) nakon što je detaljno istražen njegov predmet-dosije, omogućen mu je put kretanja po konkursu i kao ishod na osnovu njegovih vrednosti, prijem u radni odnos. Građanin koji je predmet studije slučaja u Srbiji, nije počinio nijedan delikt... odgovoran je zbog člana porodice.

${ }^{44}$ Po svojoj prirodi svaki čovek je slobodan. Ljudi su različiti po svojim posebnim prilikama i osobenostima, ali ta se različitost ne tiče apstraktne (tj. opšte) volje kao takve... Jedan broj autora stoji na stanovištu da se povredom prava nekog pojedinca vređaju svi u svome pravu...

${ }^{45}$... iz istraživanja uočavamo da građanin koji je aplicirao na konkurs državnog organa u Srbiji nema braću Kapone... a iz studije slučaja demokratske države razumemo da to nije prepreka..

${ }^{46}$ Michael R. Gottfredson and Don M. Gottredson: Decision_Making in Criminal Justice: Toward the Exercise if Discreption, $2^{\text {nd }}$ ed, New York, Plenum Pres, 1988.

47 ... jedan od primera navode autori o kolektivnom kažnjavanju je 'Rubašovljev slučaj: Vi i vaši... izazvali ste napuklinu u telu partije... '. Određenog čoveka kažnjavaju, a ne nekog drugog, zato što je on kriv... John Rawis: "Two Concepts of Rules", u Thomson, J. J., and Dworkin, G. (eds), Harper and Row, New York, 198, p. 107-108. 
na konkurs rođen/a od surogat majke (razume se legitimno)?; v) kada je podnosilac dokumenata na konkurs rođen/a iz banke veštačke oplodnje (što je legitimno pravo i dostignuće savremene civilizacije); g) podnosilac dokumenata na konkurs rođen/a u drugoj državi kao i njegovi roditelji (imaju državljanstvo države koja je raspisala konkurs) i mnoga druga pitanja... koja iz aspekta obima rada ne možemo navoditi. Iz navedenog, zaključuju autori, građanin na konkursu je odgovoran samo za svoje postupke, a ne i za postupke drugih. Njegovi postupci su u postupku sprovođenja procesa personalne bezbednosne provere u skladu sa pravnim, bezbednosnim i etičkim ${ }^{48}$ principima ili nisu. Dakle, stanovište je pravne misli u demokratskim društvima: odgovornost je individualna. ${ }^{49}$

\section{Pravni aspekti bezbednosne provere u Srbiji}

Ako pođemo od činjenice da su osnovni principi demokratskog društva zaštita ljudskih prava, onda to podrazumeva da svaka delatnost državnih organa u demokratskom društvu koja je u bilo kakvom kontekstu sa ljudskim pravima, mora biti zasnovana na zakonu ili drugom propisu koji je u skladu sa zakonom. Da li je to baš tako iz aspekta delatnosti državnih organa u Republici Srbiji, pokušali smo da sagledamo analizom pojedinih odredbi zakona kojima je ta oblast eksplicitno ili implicitno propisana. Sagledajmo najpre šta je o tome propisano u Ustavu Republike Srbije, ${ }^{50}$ odnosno u njegovim odredbama koje se tiču prava na jednaku pravnu zaštitu i na pravno sredstvo. Naime, odredbama čl. 36. Ustava, propisano je da svako ima pravo na žalbu ili drugo pravno sredstvo protiv odluke kojom se odlučuje o njegovom pravu, obavezi ili interesu koji je zasnovan na zakonu. Sa druge strane, odredbama čl. 60., svakome se jemči pravo na rad u skladu sa zakonom, odnosno pravo na slobodan izbor rada i dostupnost svih radnih mesta pod jednakim uslovima. Da li "negativna“ bezbednosna provera daje pravo svakome prema kome se takva provera vrši, da uloži žalbu ili dobije obrazloženje o odluci koju je državni organ doneo u postupku odlučivanja o njegovom pravu na rad i slobodan izbor rada, odnosno dostupnost svih radnih mesta pod jednakim uslovima? ${ }^{51}$ Ovakav način povrede ljudskih prava se u svim slučajevima ili u najvećem broju slučajeva svrstava u domen diskrecionog prava državnog organa ili se podvodi u kategoriju „zaštite bezbednosti Republike Srbije“, koja je toliko uopšteno i apstraktno definisana da različitim - proizvoljnim tumačenjem daje široku mogućnost zlouprotreba, naročito kada se tumači od strane službi bezbednosti.

S obzirom da se bezbednosne provere po pravilu vrše za zasnivanje radnog odnosa u organima državne uprave (od 2013. godine i za potrebe subjekata privatne bezbednosti), nadalje smo se bavili pojedinim odredbama zakona koji su vezani za ovu oblast. Odredba-

\footnotetext{
${ }^{48} . .$. razume se, misli se na ličnu etiku, znači-moral, vrednosti pojedinca...

49 ...iz aspekta pravne teorije i stručne javnosti u demokratskim društvima nije dozvoljeno da se primena tzv. mekog prava ostvaruje ili omeđuje aktima niže snage nego što su nacionalni zakoni (opšti pravi akti, nikako interni) ili međunarodni ugovori...

50 "Službeni glasnik RS", br. 98/2006.

51 ... odredbama Zakona o tajnosti podataka propisano je da je "podatak od interesa za Republiku Srbiju svaki podatak ili dokument kojim raspolaže organ javne vlasti, koji se odnosi na teritorijalni integritet $i$ suverenitet, zaštitu ustavnog poretka, ljudskih i manjinskih prava i sloboda, nacionalnu i javnu bezbednost, odbranu, unutrašnje poslove i spoljne poslove”... (“SI. gl. RS”, br. 104/2009).
} 
ma Zakona o policiji ${ }^{52}$ koji se tiču radnih odnosa, propisani su posebni uslovi koje kandidat za prijem u radni odnos mora da ispuni, a jedan od posebnih uslova jeste da se za kandidata izvrši bezbednosna provera, odnosno da se utvrdi da li za njega postoje ili ne postoje bezbednosne smetnje (čl. 137). Ovde nije sporna provera podataka o licu - kandidatu (personalna provera), već provera podataka kojima se utvrđuje postojanje ili nepostojanje bezbednosnih smetnji (bezbednosna provera lica bliskih kandidatu) od čijeg ishoda (pod pretpostavkom da kandidat ispunjava sve ostale opšte i posebne uslove) zavisi dalja "sudbina“ kandidata, ili konkretnije ako se na osnovu izvršenih provera utvrdi da postoje bezbednosne smetnje, onda se kandidatu odbija zahtev za prijem u radni odnos, što praktično znači da mu je svaka mogućnost ponovnog podnošenja zahteva za zasnivanje radnog odnosa apsolutno isključena i to po pravilu ne samo za rad u policiji već i u svim ostalim organima državne uprave, u kojima je bezbednosna provera neophodna. Ono što je po našem tumačenju najspornije jeste što kandidat ni na koji način ne može da dobije informaciju o tome koji su ga podaci u okviru bezbednosne provere učinili nepodobnim za zasnivanje radnog odnosa i nemogućnost podnošenja žalbe na takvu odluku. Dakle, bezbednosna smetnja koja za kandidata ima određen stepen tajnosti - poverljivosti, neosporno predstavlja osnov kršenja njegovih ljudskih prava. Zakon o policiji ide čak i dalje, pa je odredbama čl. 168. propisan prestanak radnog odnosa policijskom službeniku zbog nastalih bezbednosnih smetnji, bez prava na žalbu ali sa pravom pokretanja upravnog spora.

Odredbama Zakona o izmenama i dopunama Zakona o organizaciji i nadležnosti državnih organa u suzbijanju organizovanog kriminala, ${ }^{53}$ koje se tiču bezbednosnih provera za lica koja vrše funkciju, odnosno obavljaju poslove i zadatke u državnim organima i posebnim organizacionim jedinicama (Tužilaštvo za organizovani kriminal, Služba za suzbijanje organizovanog kriminala, Posebna odeljenja nadležnih sudova, Posebna pritvorska jedinica), propisano je da bezbednosne provere za ova lica vrši Policija, Bezbednosno informativna agencija i Vojno bezbednosna agencija, koje se mogu vršiti i bez znanja tih lica pre stupanja na funkciju, tokom vršenja funkcije i godinu dana po isteku vršenja funkcije (čl. 16). Način obavljanja bezbednosnih provera uređuje se aktom Vlade, a prikupljeni podaci predstavljaju službenu tajnu. Dakle i ovim Zakonom (tačnije Vladinim aktom) vrši se selekcija kadrova koji obavljaju veoma značajnu državnu funkciju, a naročito sporna odredba jeste što se bezbednosna provera može vršiti i bez njihovog znanja, odnosno bez njihove saglasnosti. Ovo praktično znači da se potencijalni kandidat za vršenje funkcije u nekom od navedenih organa može proglasiti nepodobnim bez prava da bude obavešten o saznanjima koja ga takvim čine.

\section{Zaključno razmatranje}

Istraživanje ukazuje da je u Republici Srbiji pri sprovođenju bezbednosne provere na delu kolektivna odgovornost porodice, odnosno lica bliskih subjektu bezbednosne provere.

Rezultat istraživanja takođe ukazuje, da je u demokratskim društvima i državama vladajući princip pri sprovođenju bezbednosne provere i utvrđivanju bezbednosnih smetnji individualna odgovornost i vrednost podnosioca prijave na konkurs.

\footnotetext{
52 “Službeni glasnik RS”, broj 6/2016.

53 “Službeni glasnik RS“, br. 72/2009 od 31. avgusta 2009.
} 
Personalna bezbednosna provera u demokratskim društvima i državama kao što ukazuju rezultati istraživanja, se sprovodi nad podnosiocem prijave - građaninom koji je aplicirao na konkurs za rad u državnom organu.

Uočavamo iz istraživanja, da je u Srbiji građaninu moguće uskratiti bezbednosnom proverom mogućnost da iskaže svoje vrednosti na osnovu „smetnje“ drugog, uz diskreciono pravo da organ veruje da će građanin kome uskraćuje pravo počiniti zločin u budućnosti. Ovde nije reč o nenamernom kažnjavanju nevinog građanina, već o svesnom i namernom uskraćivanju prava nevinom građaninu. Teorija ovakav pristup poznaje kao pristup zločina redukcije i represije ljudskih prava.

U demokratskim društvima i državama, građanin se nakon sprovedenog postupka bezbednosne provere, na razuman način obaveštava i upućuje na razlog zbog kojih njegov profil ne odgovara kriterijumima za rad u državnom organu.

Personalna bezbednosna provera u Srbiji se sprovodi bez procene izvora i saznanja iz izvora.

U demokratskim društvima, bez procene validnosti izvora i saznanja iz izvora, personalna bezbednosna provera nema pravni kapacitet (zakonitost) i na njoj se ne može temeljiti odluka - bezbednosna smetnja.

Rezime zaključnog razmatranja: iz rezultata istraživanja nalazimo da u Republici Srbiji u pravnoj i bezbednosnoj praksi državnih organa personalna bezbednosna provera, davanje ili uskraćivanje bezbednosne dozvole se temelji na: a) kolektivnoj krivici porodice - odgovornost koja je nepoznata u pravnoj teoriji i praksi prosvećenih naroda; b) krivici i kazni za neučinjeni delikt - pretpostavka da će član porodice aplikant na konkursu za rad u državnom organu počiniti delikt (prekršaj ili krivično delo), ako je to učinio član njegove porodice; v) jednom od najtežih oblika diskriminacije - nejednakosti pristupa građana javnoj službi, nepostojanju pravnih pravila i etičkog kodeksa iz oblasti personalne bezbednosne provere - već na ad hoc stanovištu organa koje se prekriva diskrecionim pravom, internim aktima i aktima Vlade, uskraćivanju prava na pravni lek.

\section{Predlog:}

Da organi u sistemu bezbednosti Republike Srbije, de lege lata primenjuju dosledno pravila koja je ova zemlja potpisala i ratifikovala, a ne propise kojima nedostaje zakonski karakter (instrukcije i dr.) jer njihova sadržina nije relevantna za primenu u svrhu sprovođenja bezbednosne provere i utvrđivanja bezbednosne smetnje.

De lege ferenda, da Vlada shodno članu 21. Univerzalne deklaracije o ljudskim pravima, gde se kaže ... 'da će volja naroda biti osnova vlasti vlade...' kao davalac ovlašćenja organima u sistemu bezbednosti, predloži Zakone kojima bi se dosledno primenjivale obaveze koje je Republika Srbija preuzela potpisivanjem i ratifikovanjem međunarodnih pravnih pravila... a koja se tiču prava građanina da mu bude dostupna, pod opštim uslovima jednakosti, svaka javna služba u Republici Srbiji... gde je bezbednosna provera sastavni deo procesa prijema, a odsustvo bezbednosnih smetnji uslov zasnivanja radnog odnosa u javnoj službi.

Da se u radu organa koji sprovode bezbednosnu proveru i utvrđuju bezbednosne smetnje, uvedu pravna, etička i bezbednosna pravila, metode i tehnike demokratskih društava i država-prosvećenih naroda. 
Na osnovu rezultata istraživanja predlaže se da zakonodavni organ donese pravna akta opšte važnosti kojima bi uredio ovu oblast.

Da se donese etički kodeks ponašanja organa, službi, agencija - svih onih državnih institucija za koje je odgovorna država, koje vrše personalnu bezbednosnu proveru integralno ili eksterno za aplikanta na konkurs za prijem u radni odnos u javnoj službi.

Da organi u čijoj je nadležnosti vršenje bezbednosne provere i utvrđivanje bezbednosne smetnje za svako saznanje iz izvora vrše procenu validnosti izvora i saznanja, tako što bi u fus noti bilo vidljivo: ko je izvor i njegov iskaz, validnost izvora i iskaza, kao i pitanje koje je postavljeno sa odgovorom koji je izvor dao.

Da se organi, službe, agencije koje vrše bezbednosne provere obavežu opštim pravnim aktom, da su dužni na zahtev građanina da ga na "razuman" način obaveste o nalazu, sa pravom da obmanjujuće i netačne iskaze iz izvora može sporiti i razjasniti u postupku pred nadležnim organima.

Da se napusti model odgovornosti aplikanta na konkurs za rad u državnom organu, na osnovu kolektivne odgovornosti porodice.

Da se napusti model po kome u bezbednosnoj praksi u Srbiji, delikti roditelja predstavljaju teret za decu, što je protivno međunarodnim pravnim pravilima koje je Srbije ratifikovala.

Da se primenjuje pravni princip individualne odgovornosti i etički principi individualne odgovornosti aplikanta na konkursu za prijem u radni odnos u državnom organu.

Da se napusti model pretpostavke činjenja delikta aplikanta na konkursu na osnovu delikta člana porodice.

Da komisija za prijem aplikanta na konkursu u radni odnos u državnom organu bude mešovitog sastava. Da jedan ili dva člana u zavisnosti od broja članova komisije bude/u civilna/o lica iz civilne kontrole službi (skupštine).

Da se formira Komisija (Skupštine - tela za bezbednost) sa posebnim ovlašćenjima koja bi na osnovu prigovora podnosioca prijave na konkursu, razmatrala dosije i donosila odluku, da li je dozvoljena žalba sudu.

\section{Literatura}

[1] Amitov Acharya, The Quest for Identity, International Relations of Soutbeast Asia, Oxford, Oxford University Press, 2000.

[2] Asbjorn Eide, etal. eds: The Univerzal Deslaration of Human Rights: A Comentary, Oslo: Scandinavian University Press; Oxford University Press, 1992.

[3] Claudia Aradau: Security and the democratic scene: Desecuritization and emancipation. Journal of International Relations and Development, 2004, 7(4): 388-413.

[4] Dinah Shelton, et. al.: Protecting human rights in the Americans: Selected problems, 3rd ed, Kehl, N. P. Engel, 1990.

[5] Executive order 10140 secutity regimenants for govermennt ebuployment, ftc. gov

[6] Hannah Arendt: The Human Condition. Chicago, IL: Chicago University Press, 1985.

[7] lan Johnstone: Dilemmas of robust peace operations' in Annual Reviw of Global Peace Operations, Boulder, Lynne Reiner, 2006.

[8] Jack Donnelly: Human Rights in Theory and in Practice, Ithaca, New York, Cornell University Press, 1989. 
[9] John Rawis: "Two Concepts of Rules", in Thomson, J. J., and Dworkin, G. (eds), Harper and Row, New York, 1988.

[10] Luis, F. Molina: Comments in the universality of the code of conduct for law enforcement officials - Third world legal studies 59, 1990.

[11] Michel Akehurst: Modern Introduction to International Law, 6th ed, New Delhi, UBS, 1992.

[12] Michael R, Gottfredson and Don M. Gottredson: Decision_Making in Criminal Justice: Toward the Exercise if Discreption, $2^{\text {nd }}$ ed, New York, Plenum Press, 1988.

[13] Security Document constitutes a violation of Title 18, United States Code, Section 101, and Article 107 of the Uniform Code of Military Justice (UCMJ).

[14] Smith Amendment, the FY01 Defense Authorization Act amended Chapter 49 of Title 10, United States Code.

[15] Constitution and statutes of the United States, including section 1753 of the Revised Statutes of the United States (5 U. S.C. 631); the Civil Service Act of 1883 (22 Stat. 403; 5 U. S.C. 632, et seq.); section 9A of the act of August 2, 1939, 53 Stat. 1148 (5 U. S.C. 118j); and the act of August 26, 1950, 64 Stat. 476 (5 U. S.C. 22-1, et seq.), and as President of the United States, and deeming such action necessary in the best interests of the national security.

[16] Questionnaire for national security politions Personnel Security Questionnaire.

[17] The provisions of Executive Order 10450 of Apr. 27, 1953, appear at 18 FR 2489, 3 CFR, 1949-1953 Comp., p. 936, unless otherwise noted.

[18] Thomas Buergenthal: International Numah Rights, St. Paul, Minn, USA, West Publishing, 1988.

[19] Ustav Republike Srbije, „Službeni glasnik RS“, br. 98/2006.

[20] Zakona o tajnosti podataka („Službeni glasnik RS ”, br. 104/2009).

[21] Zakon o policiji „Službeni glasnik RS“, broj 101/2005.

[22] Zakona o organizaciji i nadležnosti državnih organa u suzbijanju organizovanog kriminala, ....,Službeni glasnik RS“, br. 72/2009 od 31. avgusta 2009.

[23] Službeni list SFRJ - Međunarodni ugovori", br. 15/1990.

[24] Službeni list SFRJ - Međunarodni ugovori", br. 7/1971. 